\title{
A group of genes required for pattern formation in the ventral ectoderm of the Drosophila embryo
}

\author{
Ulrike Mayer and Christiane Nüsslein-Volhard \\ Max Planck Institut für Entwicklungsbiologie, Tübingen, FRG
}

\begin{abstract}
Mutations in the genes spitz (spi), Star (S), single-minded (sim), pointed (pnt), rhomboid (rho) (all zygotic), and sichel (sic) (maternal), collectively called the spitz group, cause similar pattern alterations in ventral ectodermal derivatives of the Drosophila embryo. The cuticle structures lacking in mutant embryos normally derive from longitudinal strips of the ventro-lateral blastoderm. Defects were found in the median part of the central nervous system in whole-mount embryos stained with anti-HRP (horseradish peroxidase) antibodies. In addition, the nerve cells expressing the even-skipped protein appeared abnormally arranged. These results suggest that groups of cells from the same region, including both epidermal and neural precursor cells, require spitz-group gene activity for normal development. The members of the spitz group differ from one another: sim affects a more median strip of the ventral ectoderm than the other zygotic genes and pnt causes separation rather than deletion of pattern elements. As shown by pole cell transplantations, spi and $S$ are also required for normal development of the female germ line, while sim, rho, and pnt appear to be exclusively zygotically expressed, and the maternal gene sic acts in the germ line autonomously. Some embryos produced by sichomozygous females differentiate the spitz phenotype, others develop normally or die early. Of all the spitzgroup genes, sim appears to have the most specific effect on the embryonic pattern. The significance of the spitz-group phenotypes for the dorso-ventral pattern formation is discussed.
\end{abstract}

[Key Words: Drosophila embryo; spitz group; ventral ectoderm; dorso-ventral pattern]

Received April 25, 1988; revised version accepted September 2, 1988.

The fate map of the Drosophila embryo along the dorsoventral axis at the blastoderm stage can be described as a series of longitudinal stripes. The anlage of the mesoderm is located midventrally, followed by the broad region of the ventral and then dorsal ectodermal anlagen. Along the dorsal midline, the anlagen of the rudimentary amnioserosa are located. Although these anlagen are somewhat distorted in the head and tail region of the embryo, in the large, segmented middle region of the embryo they exhibit a clear parallel alignment (LohsSchardin et al. 1979; Campos-Ortega and Hartenstein 1985).

The formation of the dorso-ventral pattern of the Drosophila embryo depends on the activity of a small number of maternal-effect genes (for review, see Anderson 1987). Their phenotypes and properties indicate that they are integrated into a single system which provides positional information for the developing embryo. Lack of function mutations of any of the dorsal group genes result in dorsalized embryos in which all regions along the dorso-ventral axis develop according to a program normally followed by cells in the middorsal region. A partially ventralized phenotype is caused by gain of function mutations of the gene Toll as well as lack of function mutations of the cactus gene. Genetic evidence as well as transplantation experiments suggest that Toll is involved in the determination of polarity, while the gene product of the dorsal gene functions as the morphogen that determines dorso-ventral position in the embryo (Anderson et al. 1985a,b).

A set of zygotically expressed genes responds to this maternal information. Although both dorsalized and ventralized phenotypes may be produced by mutations in zygotically active genes, the effect on the fate map is never as strong as that of a maternal-effect mutation. The genes twist (twi) and snail are required for the formation of the ventral-most anlagen, including the mesodermal anlage (Nüsslein-Volhard et al. 1984). Mutations in these genes result in absence of the ventral furrow and a partially dorsalized phenotype resembling that of weak dorsal mutations. The twist gene has been cloned and shown to be expressed in a longitudinal stripe along the ventral midline (Thisse et al. 1987). Mutations in a group of five zygotically expressed genes show a partially ventralized phenotype. Of these, decapentaplegic $(d p p)$ and zerknüllt (zen) have been cloned. The expression pattern of $d p p$ starts in the blastoderm with a broad dorsal region of expression which narrows and is subsequently split into parallel bands of dorso-lateral expression (St. Johnston and Gelbart 1987). zen is expressed 
early in a narrow middorsal stripe, a pattern consistent with the lack of amnioserosa cells in zen embryos (Wakimoto et al. 1984; Doyle et al. 1986). While the analysis of these genes and their interactions is still in progress, it may be tentatively assumed that they cooperate in establishing the dorsal and ventral poles of the transverse pattern. In addition, the mutant phenotypes of the neurogenic genes show a transformation to central nervous tissue of the ventral, but not the dorsal epidermis (Lehmann et al. 1983), indicating a further subdivision of the dorso-ventral axis. However, zygotically expressed genes responsible for the primary subdivision of the ectodermal region have not been unequivocally identified.

In this paper we describe a group of genes that appear to be involved in a further specification of the ventral ectodermal region. The phenotypes of mutants of the spitz-group genes have in common that the lateral extent of the ventral epidermal pattern is reduced. A corresponding reduction is also observed in the central nervous system. The genes Star $(S)$, spitz (spi), rhomboid (rhol, and pointed (pnt) were identified in systematic screens for embryonic lethal mutations affecting the pattern of the larval cuticle (Jürgens et al. 1984; Nüsslein-Volhard et al. 1984). One allele of single-minded (sim) (Thomas et al. 1988) was fortuitously isolated and identified as a member of the spitz group and as an allele of the previously known locus 1/3)S8 (Hilliker et al. 1981) by Jürgens (pers. comm.). Last, one maternal locus, sichel (Mayer 1986) was identified in a large-scale screen for maternal-effect mutants /C. Nüsslein-Volhard et al., unpubl.). We show that the spitz-group genes are required for normal development of the descendants of the blastodermal cells adjacent to the midventral mesodermal precursor cells. Based on phenotypic differences between sim on the one hand and $S, s p i$, rho, and pnt on the other hand, this ventro-lateral region can be resolved further into a more medial and a lateral stripe. In both of these regions, epidermal as well as neural cells are affected.

\section{Results}

Mutations in five loci of the spitz group (Table 1) all cause zygotic lethality with similar embryonic phenotypes (Fig. 1). The width of the ventral denticle bands is reduced and the right and left parts of the head skeleton are fused such that it appears pointed (spitz). These are the common features of the spitz-group phenotype; slight differences between the members of the group will be described below. The maternal-effect gene sichel (sic) (Table 1), represented by four mutant alleles that also produce the cuticle phenotype described above (Fig. $1 \mathrm{~g}$ ), will be regarded as a sixth member of the group in the characterization of the spitz embryonic phenotype. However, as we will show, the spitz phenotype of the sic alleles is only one aspect of a more complex syndrome (see below).

\section{The mutant cuticle pattern: the segmented region}

The spitz-group phenotype as revealed in cuticle preparations suggested to us that the dorso-ventral pattern is changed in mutant embryos. Although the entire length of the embryo, from head to tail, is affected, we will first describe the mutant pattern in the segmented region of the larva, which, in the wild type, most clearly displays a well-defined, ventro-dorsal sequence of pattern elements. We will subsequently examine the pattern defects in the head and tail to see whether they occur at corresponding dorso-ventral positions.

For convenience, the continuous pattern of the dorsoventral axis may be subdivided into four regions, ventral, ventro-lateral, dorso-lateral, and dorsal, which are marked by ventral denticles, lateral denticles, lateral hairs, and dorsal hairs, respectively. The ventro-lateral and dorso-lateral regions are separated by the lateral midline, along which the lateral sensory hairs are located (for details, see Lohs-Schardin et al. 1979). Additional landmarks of dorso-ventral positions are present in the thoracic segments: The Keilin's organs, groups of

Table 1. Genes of the spitz group

\begin{tabular}{|c|c|c|c|c|}
\hline Locus & $\begin{array}{l}\text { Map } \\
\text { position }\end{array}$ & Cytology & Alleles $^{a}$ & References $^{b}$ \\
\hline \multicolumn{5}{|l|}{ Zygotic: } \\
\hline spitz (spi) & $2-54$ & $37 \mathrm{E} 2-38 \mathrm{E}$ & IIA14, IIT25 & 1 \\
\hline Star $(S)$ & $2-1.3$ & 21D2-22A1 & IIN23, $1(2) 54$ & 1 \\
\hline pointed (pnt) & $3-79$ & $(94 E)$ & $9 丁 31,8 \mathrm{~B} 74$ & 2 \\
\hline rhomboid (rho) & $3-3$ & $(61 F-62 D)$ & $7 \mathrm{M} 43$ & 2 \\
\hline \multirow[t]{2}{*}{ single-minded $(\operatorname{sim})$} & $3-52$ & $87 \mathrm{D} 11-15$ & $1(3) \mathrm{S} 8$ & 3 \\
\hline & & & E320-5 & 4 \\
\hline \multicolumn{5}{|l|}{ Maternal: } \\
\hline sichel (sic) & $3-48.8$ & $8507-12$ & $215,256,612,371$ & 5 \\
\hline
\end{tabular}

all mutants EMS-induced, except for the sim allele 1/3)S8 which has been induced by $\mathrm{x}$ ray.

b References: 1. Nüsslein-Volhard et al. 1984. 2. Jürgens et al. 1984. 3. Hilliker et al. 1981. 4. G. Jürgens, pers. comm. 5. C. Nüsslein-Volhard et al., unpubl.; Mayer 1986. 


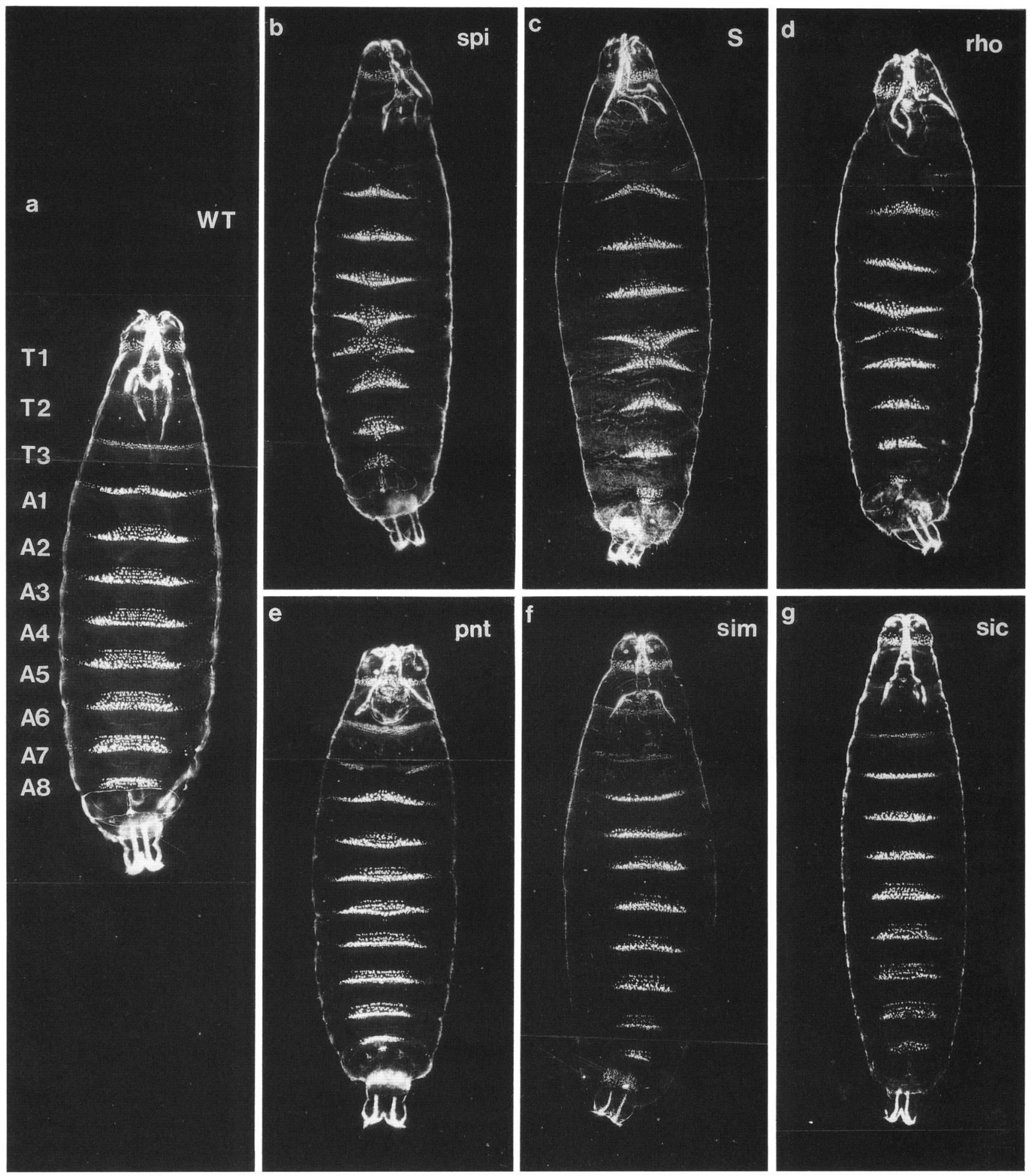

Figure 1. Ventral aspect of cuticle pattern of $(a)$ wild-type and spitz-group mutant embryos $(b-g) ;(b)$ spitz, $(c) S t a r,(d)$ rhomboid, $(e)$ pointed, $(f)$ single-minded, $(g)$ sichel. T1-T3, thoracic segments; A1-A8, abdominal segments. Dark-field photographs.

three sensory hairs, lie in the ventral region and the ventral and dorsal black dots mark the boundaries between the ventral and ventro-lateral regions and the dorso-lateral and dorsal regions, respectively (Fig. 2a).
The Keilin's organs in mutant spi, $S$, and rho embryos are missing or strongly reduced, while in sic and pnt the Keilin's organs are present but the individual hairs are often further apart than normal (Fig. 2b-e,g). Although 


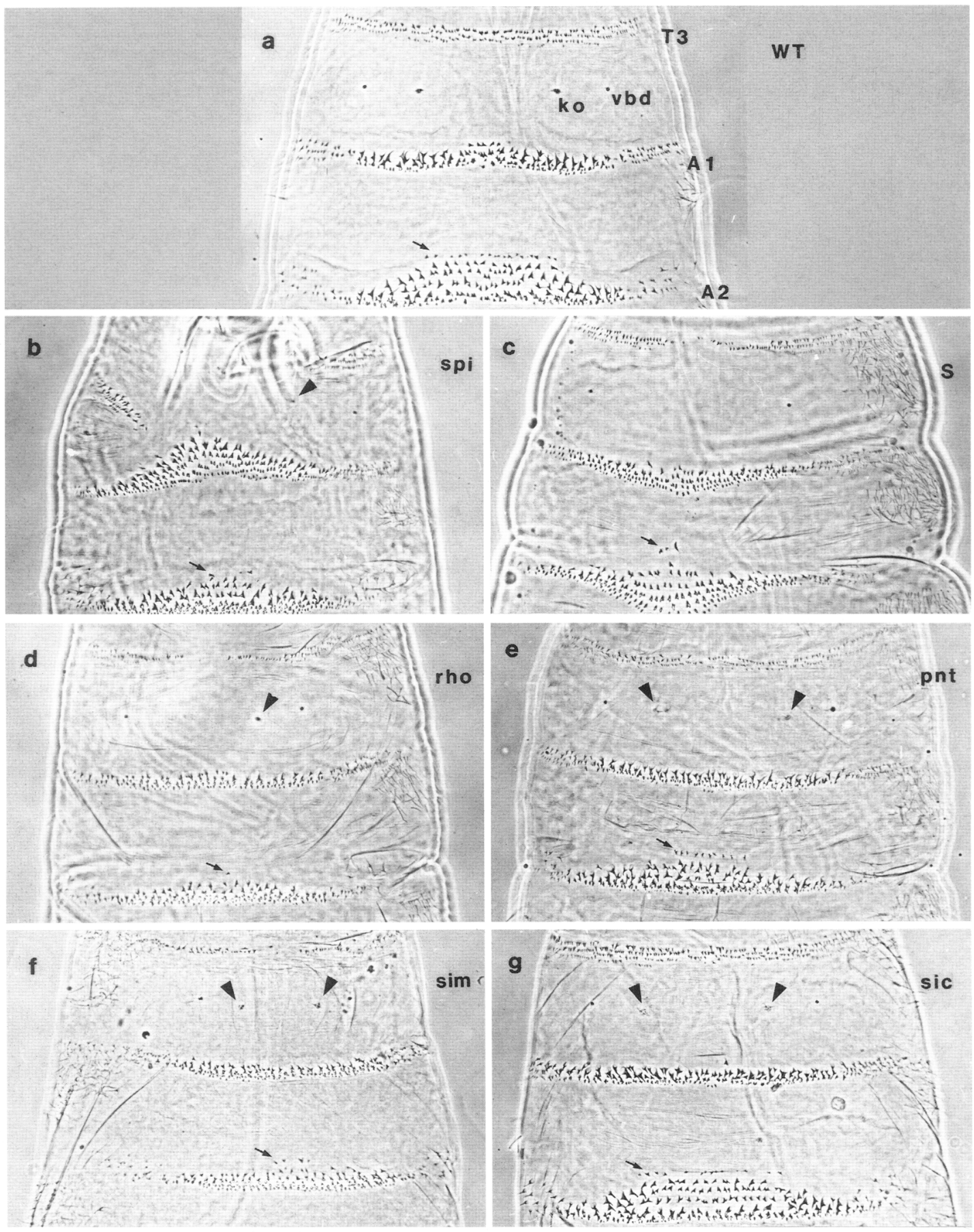

Figure 2. Central part of the segmented region of the ventral cuticle pattern of $(a)$ wild-type and spitz-group mutant embryos $(b-g)$; $(b)$ spitz, $(c)$ Star, $(d)$ rhomboid, (e) pointed, $(f)$ single-minded, $(g)$ sichel. The Keilin's organs (ko, arrowheads) are missing in $S(c)$, they are incomplete in spi $(b)$ and rho $(d)$, and abnormal in pnt $(e)$. The left and right ko are closer to one another, markedly in sim $(f)$ and less so in sic (g). The first row of the second abdominal denticle band (A2) is shorter in mutant than in wild-type embryos (arrows). (A1 and T3) Denticle bands of first abdominal and third thoracic segment; (vbd) ventral black dot. Phase-contrast photographs.

sim embryos show normal Keilin's organs, the distance between the left and the right Keilin's organ is shortened to $64 \%$ of the wild-type value (Fig. 2f; Table 2). In other mutants of the spitz group, this distance ranges from $72 \%$ to $89 \%$ of the wild-type value. The distances between the right and left ventral black dots show less reduction (between $74 \%$ and $90 \%$ ).
Denticle bands in the abdominal region normally have six rows, with the exception of the first band, which lacks the first row of denticles (Lohs-Schardin et al. 1979). The denticles of the first and the fourth rows point anteriorly, those of all the other rows point posteriorly. These changes in polarity between rows one and two and rows four and five indicate the sites where the 
Table 2. Pattern changes in the segmented region of spitz-group mutant embryos

\begin{tabular}{|c|c|c|c|c|c|c|}
\hline & sichel & spitz & Star & rhomboid & single-minded & pointed \\
\hline Keilin's organs (KO) & hairs separate & $1-2$ hairs & absent & $\begin{array}{l}\text { frequently } \\
\text { absent }\end{array}$ & normal & hairs separate \\
\hline $\begin{array}{c}\text { Distance between pairs } \\
\text { of } \mathrm{KO} \text { (WT } 0.36 \text { ) }\end{array}$ & $(0.29) 80.5 \%$ & $|0.26| 72 \%$ & - & $(0.26) 72 \%$ & $(0.23) 64 \%$ & $(0.32) 89 \%$ \\
\hline $\begin{array}{l}\text { Distance between pairs } \\
\text { of ventral black }\end{array}$ & & & & & & \\
\hline $\begin{array}{l}\text { dots (WT 0.62) } \\
\text { Fusion of denticle }\end{array}$ & $(0.55) 89 \%$ & $(0.51) 82 \%$ & $(0.52) 84 \%$ & $(0.51) 82 \%$ & $(0.46) 74 \%$ & $(0.56) 90 \%$ \\
\hline bands & rare & frequent & frequent & frequent & none & rare \\
\hline Dorsal surface & normal & normal & $\begin{array}{c}\text { defective } \\
\text { dorsal } \\
\text { closure }\end{array}$ & $\begin{array}{c}\text { defective } \\
\text { dorsal } \\
\text { closure }\end{array}$ & normal & $\begin{array}{c}\text { defective } \\
\text { dorsal } \\
\text { closure }\end{array}$ \\
\hline Lateral sensory hair & normal & normal & normal & normal & normal & normal \\
\hline
\end{tabular}

muscles attach to the epidermis (Szabad et al. 1979). Mutant embryos frequently lack the first row and do not show the reversed polarity of the fourth row (Fig. 2). These defects are predominantly seen in the anterior half of the abdomen. In addition, spi, $S$, and rho show irregular fusions of neighboring denticle bands along the ventral midline (Fig. $1 \mathrm{~b}-\mathrm{d}$ ), while sic and the pnt $t^{9 / 31}$ allele do so rarely and sim never (Table 2). Pattern irregularities are also observed along the dorsal midline in $S$, rho, and pnt embryos (Table 2).

The mutant cuticle pattern: head and tail

Most head structures of the wild-type larva, such as the sclerotized, strongly pigmented head skeleton, are found inside the thorax of the larva as a result of head involu- tion. The most prominent structures of the head are the mouth hooks, the sensory structures of the antennomaxillary complex, and the cirri (Fig. 3a,g; cf. Jürgens et al. 1986). The morphogenetic movements that occur during head development obscure the topographical relationship of the head structures (see below).

The spitz-group mutations affect the head structures in a characteristic manner. Some head structures, such as the mouth hooks and the cirri, look normal in all mutants, while others, including the head skeleton and the floor of the pharynx, are invariably affected (Table 3 ). The latter two structures are fused ventrally, which causes the characteristic appearance of the head in the spitz-group mutants (Fig. 3f,h). Labrum, antenno-maxillary complex, and labial sensory organ are markedly
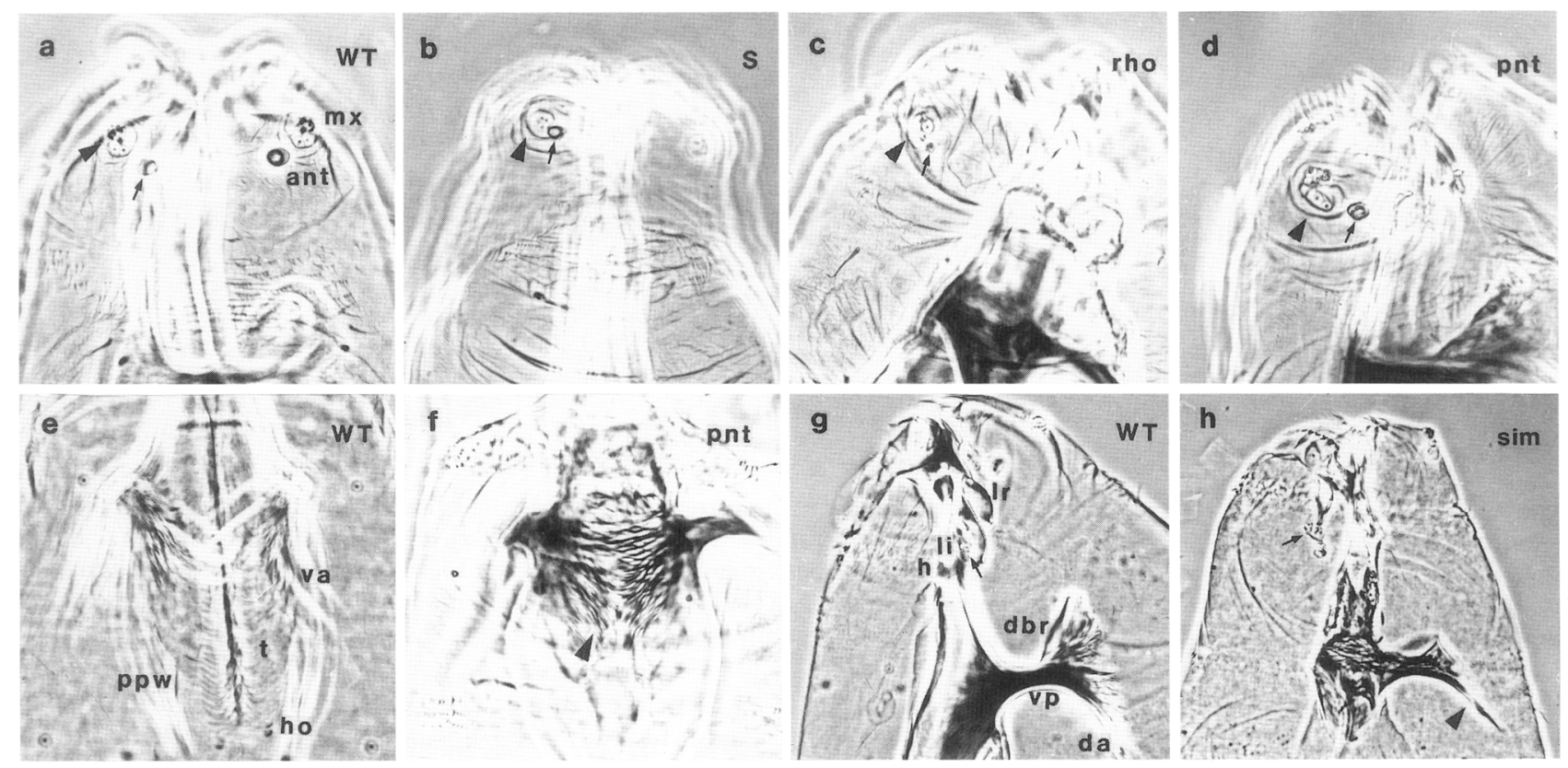

Figure 3. Head structures of $(a, e, g)$ wild-type and $(b-d, f, h)$ mutant embryos. (Dorsal aspect $a-d)$ The antennal (ant, arrow) and maxillary (mx, arrowhead) sense organs are smaller in $S(b)$ and $r h o(c)$, but larger in pnt $(d)$ than in wild type. (Ventral aspect $e, f)$ The ventral arms (va) of the head skeleton are fused in mutant embryos (arrowhead). (Lateral aspect $g, h$ ) The labial sense organ (li, arrow) lies on the surface rather than inside the head. The dorsal arms (da, arrowhead) are spread apart. (dbr) Dorsal bridge; (h) H-bridge; (ho) hypopharyngeal organ; $(\mathrm{ppw})$ posterior wall of pharynx; (t) T-ribs; (vp) vertical plate. Phase-contrast photographs. 
Table 3. Pattern changes in the head region of spitz-group mutant embryos

\begin{tabular}{|c|c|c|c|c|c|c|}
\hline & sichel & spitz & Star & rhomboid & single-minded & pointed \\
\hline Cirri & normal & normal & normal & normal & normal & normal \\
\hline Mouth hooks & normal & normal & normal & normal & normal & normal \\
\hline Ant SO & normal & small & rudimentary & small & normal & large \\
\hline Max SO & normal & small & rudimentary & small & normal & roundish \\
\hline Labrum & normal & misshapen & broad & broad & normal & wide \\
\hline Lab SO & outside & small & small & small & outside & normal \\
\hline $\begin{array}{l}\text { Dorsal structures of } \\
\text { head skeleton }\end{array}$ & $\begin{array}{l}\text { V-shaped, } \\
\text { spread }\end{array}$ & $\begin{array}{l}\text { V-shaped, } \\
\text { fuzzy }\end{array}$ & $\begin{array}{l}\text { V-shaped, } \\
\text { fuzzy }\end{array}$ & V-shaped & V-shaped & V-shaped \\
\hline $\begin{array}{l}\text { Anterior ventral } \\
\text { structures }\end{array}$ & $\begin{array}{l}\text { poorly } \\
\text { differentiated }\end{array}$ & $\begin{array}{l}\text { poorly } \\
\text { differentiated }\end{array}$ & $\begin{array}{l}\text { poorly } \\
\text { differentiated }\end{array}$ & $\begin{array}{l}\text { poorly } \\
\text { differentiated }\end{array}$ & $\begin{array}{l}\text { poorly } \\
\text { differentiated }\end{array}$ & $\begin{array}{l}\text { poorly } \\
\text { differentiated }\end{array}$ \\
\hline Ventral arms & fused & fused & fused & fused & fused & fused \\
\hline Floor of pharynx & split, narrow & split, narrow & split, narrow & split, narrow & split, narrow & split, narrow \\
\hline T-ribs & $\begin{array}{l}\text { poorly } \\
\text { differentiated }\end{array}$ & not recognizable & not recognizable & not recognizable & not recognizable & not recognizable \\
\hline Hypopharyngeal organ & normal & not recognizable & not recognizable & not recognizable & not recognizable & not recognizable \\
\hline
\end{tabular}

smaller in spi, $S$, and rho (Fig. 3b,c). These structures are enlarged and deformed in pnt embryos (Fig. 3d), while in sim and sic they are not affected noticeably. However, the labial sensory organ and the hypostomal sclerite are located abnormally in sim and sic (Fig. 3h). All the structures affected in the mutants are derived from ventral positions. Changes in the dorsal structures of the head structure appear to be secondary effects of the mutations. This is most clearly seen in the V-shaped arrangement of the dorsal arms relative to one another (Fig. 3h).

The tail region of the larva is marked ventrally by the paired anal pads and behind these at the midline, the unpaired tuft with approximately 12 denticles (Fig. 4a; cf. Jürgens 1987). On the dorsal side, paired stigmatophores bear the posterior spiracles which are connected with the dorsal longitudinal tracheal trunks.
In contrast to the head, we find no structure in the tail region that is affected similarly by all mutants of the spitz group (Table 4). Mutant sim embryos show a fusion of the right and left anal pads (Fig. 4c), while other members of the group merely have smaller anal pads which may be fused at the anterior margin (Fig. 4b). In contrast, pnt embryos have larger anal pads and more tuft denticles (Fig. 4d) relative to wild type. The tuft is clearly reduced in size in $S$ and rho. Dorsal structures such as Filzkörper, spiracles, and stigmatophores are occasionally defective in $S$, rho, and pnt embryos (Table 4). Although the defects in the tail region vary between mutants like those in the segmented region and the head region, they are confined predominantly to a ventral zone.

In all mutants of the group, a contiguous region of the ventral embryonic cuticle is affected which extends

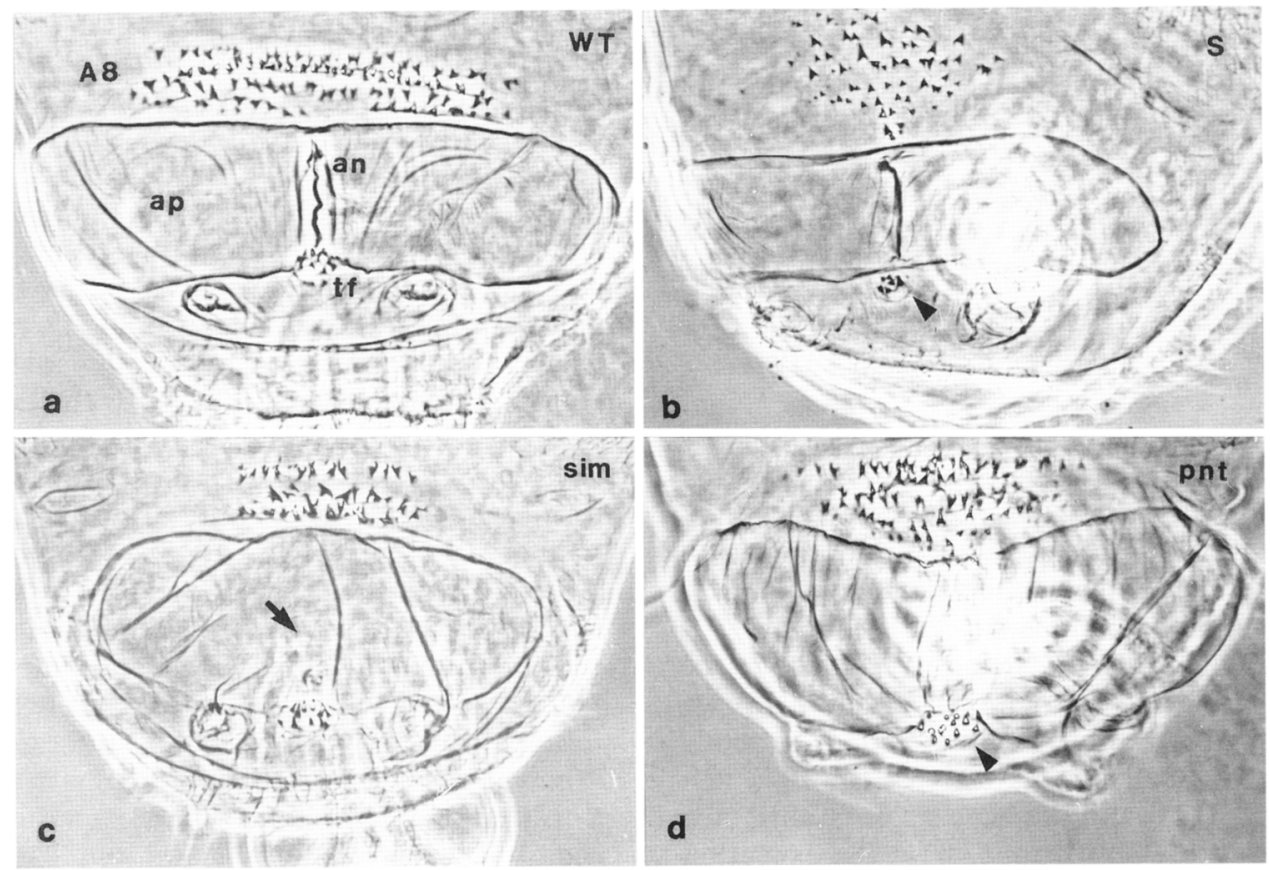

Figure 4. Ventral aspect of hind end of $(a)$ wild-type and mutant $(b-d)$ embryos. The anal pads (ap) are smaller in $S(b)$, fused (arrow) in $\operatorname{sim}(c)$, and enlarged in pnt $(d)$. The tuft (tf, arrowhead) has fewer denticles in $S(b)$ but more in pnt (d) relative to wild type $(a)$. Note the different widths of the A8 denticle band. (an) Anus. Phase-contrast photographs. 
Table 4. Pattern changes in the tail region of spitz-group mutant embryos

\begin{tabular}{|c|c|c|c|c|c|c|}
\hline & sichel & spitz & Star & rhomboid & $\begin{array}{l}\text { single- } \\
\text { minded }\end{array}$ & pointed \\
\hline Anal pads & $\begin{array}{l}\text { anterior margin } \\
\text { fused, slightly } \\
\text { smaller }\end{array}$ & normal & smaller & $\begin{array}{l}\text { anterior } \\
\text { margin fused }\end{array}$ & fused & $\begin{array}{l}\text { larger, sometimes } \\
\text { anterior margin } \\
\text { fused }\end{array}$ \\
\hline Tuft & normal & normal & smaller & smaller & normal & enlarged \\
\hline Filzkörper & normal & normal & thin & thin & normal & normal \\
\hline Spiracle & normal & normal & deformed & normal & normal & normal \\
\hline Stigmatophore & normal & normal & separate & separate & normal & separate \\
\hline
\end{tabular}

from the head to the tail. However, the dorso-ventral positions of the cuticle defects differ among mutations in different genes. A midventral strip of the epidermis is affected in sim and frequently in sic embryos. This narrow zone is delimited by special sense organs in the head and thorax (antenno-maxillary complex, Keilin's organs|. Compared to sim, the defects caused by the other zygotic mutations extend into a more lateral region of the epidermis which includes the sensory organs of the antenno-maxillary complex and the Keilin's organs.

\section{Double mutants of the spitz-group genes suggest independent action}

To elucidate the relationships between members of the spitz-group genes, we studied the phenotypes of double mutants. In those combinations where the single mutations, such as rho, sim, and pnt, each produce different phenotypic effects, the phenotype of the double mutants appears to show the features of both (Fig. 5). For example, rho sim embryos lack or have reduced Keilin's organs, as do the rho embryos, and they also show the fusion of the anal pads characteristic of the sim embryos. We quantitated the phenotypic effects in rho sim embryos by measuring the distance between the ventral black dots in the third thoracic segment. This distance is reduced to $68 \%$ of the wild-type value while the single mutants $\operatorname{sim}$ and rho showed reduction to $74 \%$ and $82 \%$, respectively. The additive phenotypes of doublemutant combinations suggest that the genes of the spitz group act independently in the developing ventral epidermis of the embryo.

\section{Pattern changes in the peripheral nervous system of spitz-group mutants}

The sensory organs of the larval epidermis are composed of both neural cells of the peripheral nervous system and epidermal cells which secrete the cuticle specialization. They derive from epidermal cells which remain mitotically active after other epidermal cells have stopped dividing (Hartenstein and Campos-Ortega 1986).

To see whether changes corresponding to those in the cuticle occur in the peripheral nervous system (PNS), we stained mutant embryos with the monoclonal antibody 22C10, which specifically labels cells of the PNS ( $\mathrm{Zi}$ pursky et al. 1985). When stained with this antibody, mutant embryos of the spitz group, with the exception of sim, exhibit defects in peripheral neurons corresponding to the defects observed in the cuticle (data not shown). The changes are seen most clearly in the large antenno-maxillary complex which appears reduced in $S$, $s p i$, and rho embryos, but enlarged in pnt embryos. The defects are less pronounced in the nerve cells of the Keilin's organs consistent with the relatively slight abnormalities of their cuticle specializations. In sim embryos, sensory structures are neither missing nor abnormal in both the cuticle and peripheral neurons. We conclude from these observations that mutations in the spitz group genes affect topographically related parts of the epidermis and PNS.

\section{The central nervous system is altered in spitz-group mutant embryos}

The ventral ectoderm, from which the ventral epidermis is derived, also gives rise to the central nervous system (CNS). Therefore, it was interesting to see whether the mutations in the spitz-group genes affect only the ventral epidermis, or whether they also cause corresponding defects in the CNS.

As a marker for neural tissue, we used a polyclonal antibody against horseradish peroxidase which crossreacts with a cell-surface antigen present on postmitotic neural cells (anti-HRP; Jan and Jan 1982). In wholemount preparations of wild-type and mutant embryos we detected clear deviations from the wild-type staining pattern in all mutants (Figs. 6 and 7). In spi, $S$, and rho embryos (Fig. 7b-d), the left and the right halves of the segmental ganglia are closer together than in wild type which can be seen in a reduction of the commissures. In sim embryos (Fig. 7f), the commissures are eliminated, and the left and the right halves of the ganglia are fused ('single-minded'; Crews et al. 1988; Thomas et al. 1988). The maternal mutation sic results in slightly shorter commissures and local fusions of the connectives (Fig. $7 \mathrm{~g}$ ). The sic phenotype is in general more variable than that of the others (Fig. 6). The pnt phenotype deviates from wild type in a way different from the other members of the group. In pnt embryos, the nervous system seems to be broader and both the commissures and the connectives are interrupted (Fig. 7e). These visual impressions were confirmed by measuring the distances between the right and the left halves of the third thoracic ganglia with an ocular micrometer (Table 5). Whereas the width of this ganglion was reduced by twothirds to one-half of the wild-type value in spi, $S$, and rho, it was expanded by $75 \%$ in pnt. These results demonstrate that the genes of the spitz group act on neural as well as epidermal derivatives of the ventro-lateral region of the blastoderm. 

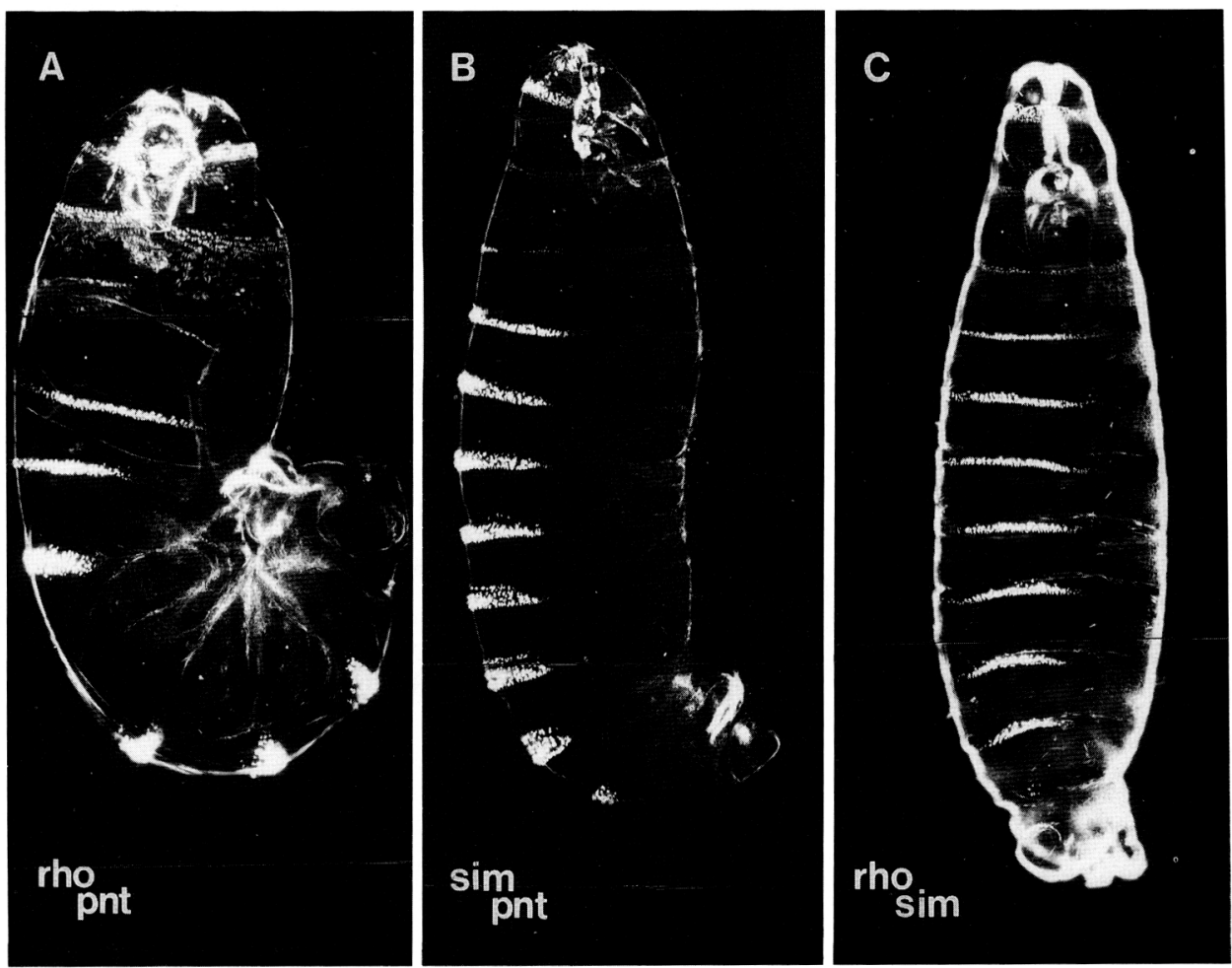

Figure 5. Dark-field photographs of double-mutant embryos. Compared with the corresponding single mutants (Fig. 1), the double mutants show abnormalities in the head and in the hind end that may be due to incomplete morphogenetic movements (see text).

To investigate the pattern changes in the CNS in more detail, we took advantage of the expression pattern of the pair-rule gene even-skipped (eve). It had been shown previously that antiserum raised against eve fusion protein recognizes a distinct and segmentally re- peated pattern of cells in the developing nervous system (Frasch et al. 1987). In the 10- to 11-hr-old wild-type embryo, clusters of labeled cells can be visualized, one cluster on each side of the midline with about 6 cells, and another cluster more lateral and somewhat posterior
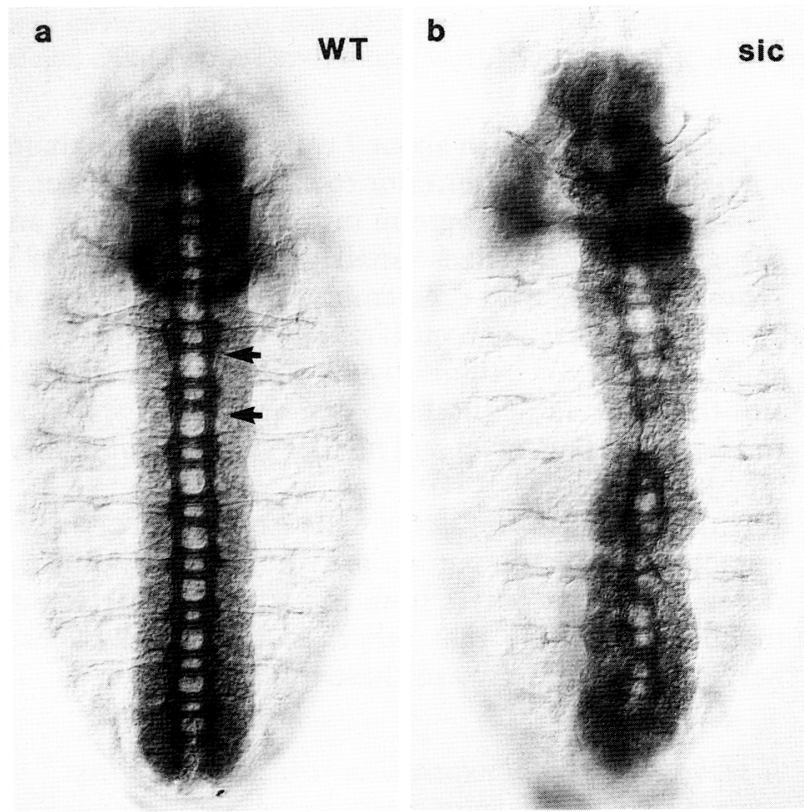

c

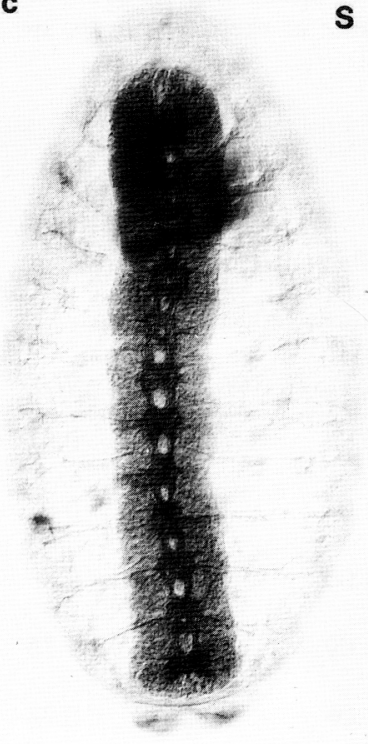

s

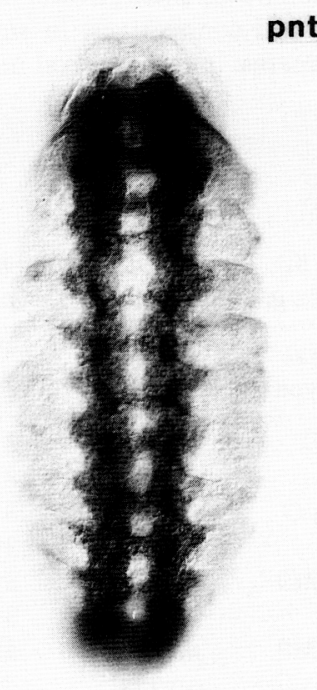

Figure 6. Central nervous systems stained with anti-HRP antibodies in whole mounts of $(a)$ wild-type and mutant $(b-d)$ embryos. The length of a single neuromere is marked by arrows in $a$. For details, see Fig. 7. Age of embryos $14 \mathrm{hr}$ after fertilization /stage 14 of Campos-Ortega and Hartenstein 1985|. 


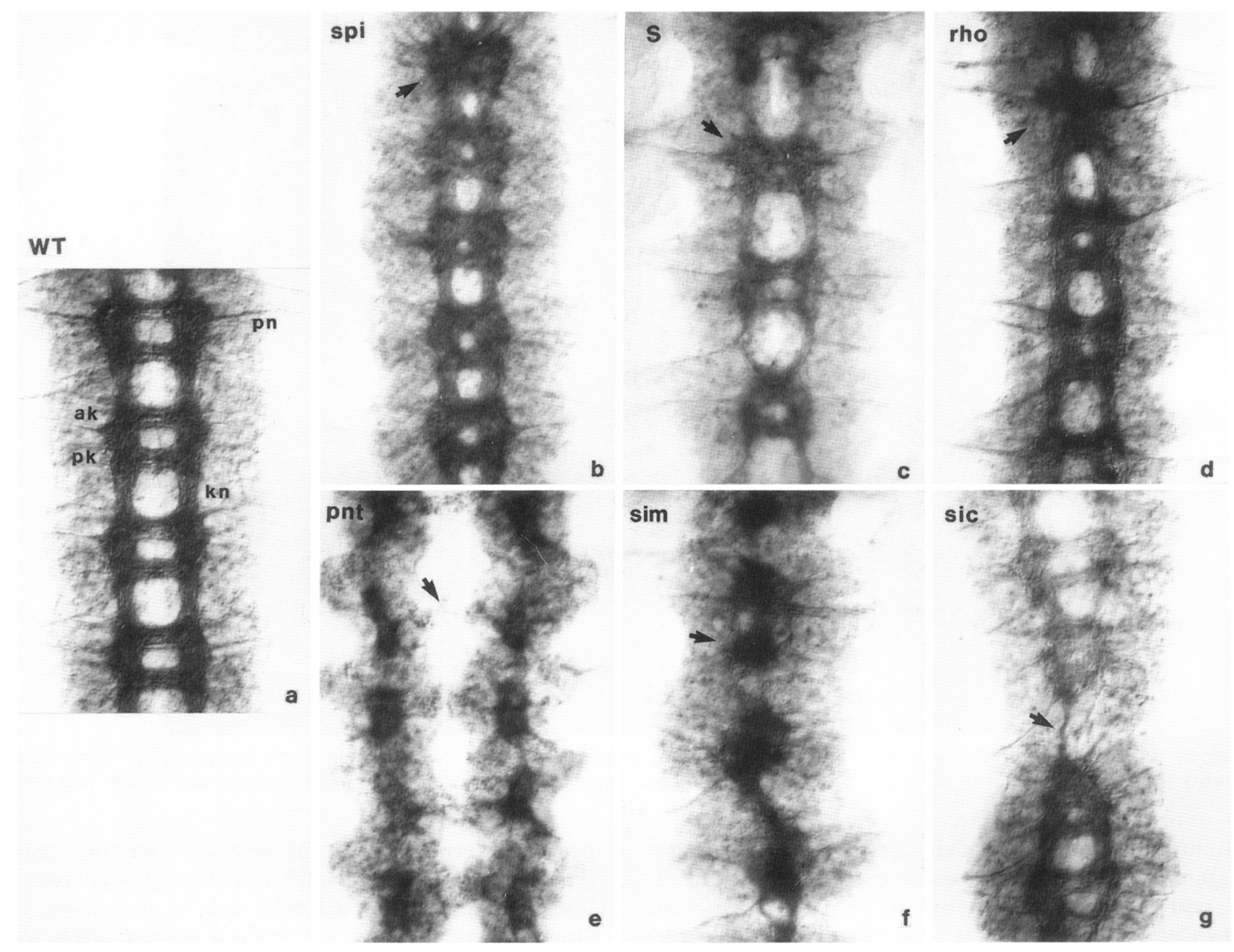

Figure 7. Details of the CNS stained with anti-HRP antibodies shown at higher magnification. The CNS of the wild type $(a)$ shows regular spacing of anterior $(\mathrm{ak})$ and posterior $(\mathrm{pk})$ commissures and connectives $(\mathrm{kn})$. sim embryos $(f)$ show complete fusion of the left and the right halves of neuromeres leaving only one strand of connectives. In $s p i(b), S(c)$, and rho $(d)$ the commissures are shortened to different extents (arrows). In pnt (e) the commissures are almost absent (arrow) and there is no clear distinction between neuromeres and connectives. In sic $(\mathrm{g})$ some of the neuromeres are fused such that a single narrow connective (arrow) links adjacent neuromeres. (pn) Peripheral nerve.

Table 5. Quantitative changes in the central nervous system of spitz-group mutant embryos

\begin{tabular}{|c|c|c|c|c|c|}
\hline $\begin{array}{l}\text { Parental } \\
\text { genotype }\end{array}$ & Phenotype & $N$ & $\mathrm{~L}_{\mathbf{M}} / \mathrm{L}_{\mathrm{WT}}$ & $\mathrm{W}_{\mathrm{M}} / \mathrm{W}_{\mathrm{WT}}$ & $\mathrm{W} / \mathrm{L}$ \\
\hline \multirow[t]{2}{*}{ S/CyO } & mutant & 8 & 0.92 & 0.52 & 0.57 \\
\hline & normal & 8 & & & \\
\hline \multirow[t]{2}{*}{ spi/CyO } & mutant & 8 & 1.07 & 0.71 & 0.66 \\
\hline & normal & 13 & & & \\
\hline \multirow[t]{2}{*}{ rho/TM3 } & mutant & 5 & 1.00 & 0.65 & 0.65 \\
\hline & normal & 5 & & & \\
\hline \multirow[t]{2}{*}{ pnt/TM3 } & mutant & 5 & 1.09 & 1.94 & 1.76 \\
\hline & normal & 8 & & & \\
\hline \multirow[t]{2}{*}{$\mathrm{sic} / \mathrm{sic}$} & mutant & 7 & 1.05 & 0.81 & 0.77 \\
\hline & normal & 5 & & & \\
\hline
\end{tabular}

$N$, number of CNSs analyzed; $\mathrm{L}$, average length /third thoracic ganglion); $\mathrm{W}$, average width (third thoracic ganglion); $\mathrm{M}$, mutant; WT, wild type. to the middle one with about 7 cells. In addition, there is a single, stained cell anterior to each middle cluster.

In the CNS of spitz-group mutant embryos, the antieve antibody recognizes small groups of cells that resemble those of wild-type embryos both in number and approximate arrangement (Fig. 8). However, the labeled cells are grouped differently in sim embryos (Fig. 8d), and the clusters lie closer to one another in spi, $S$, and rho embryos (Fig. 8b,c) and further apart in pnt embryos (Fig. 8e).

Although all of the nerve cells expressing eve appear to be present in spitz-group mutant embryos, their spatial arrangement differs from the wild-type pattern in a manner suggesting that other, more medially located nerve cells are missing in these mutants.

\section{A test for maternal expression reveals differences among the zygotic spitz-group genes}

The phenotypes described for mutants of the spitz-group genes reflect the amorphic condition in the case of spi, $S$, 

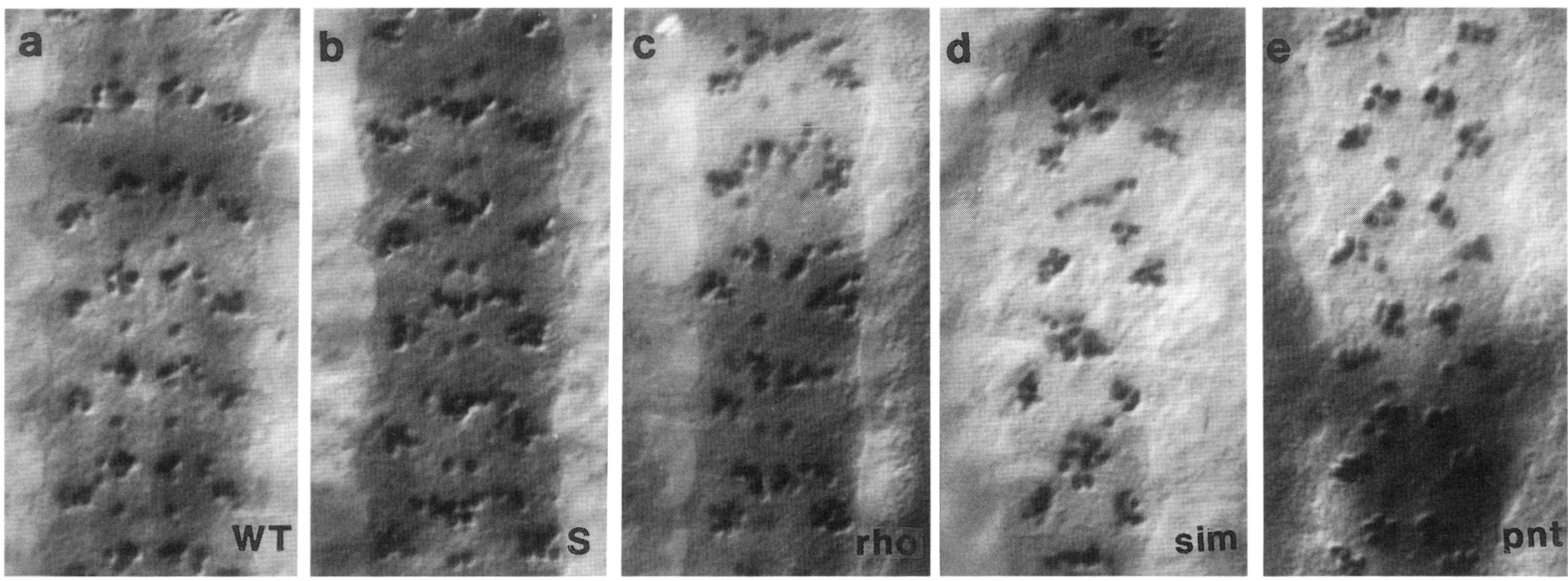

Figure 8. Details of the central nervous system stained with anti-eve antibodies. In wild type $(a)$ there is a regular repetitive pattern of stained cells. The arrangement of stained cells is modified in spitz-group mutant embryos $(b-e)$ in a way that is consistent with the alterations of mutant CNS (cf., Figs. 6 and 7).

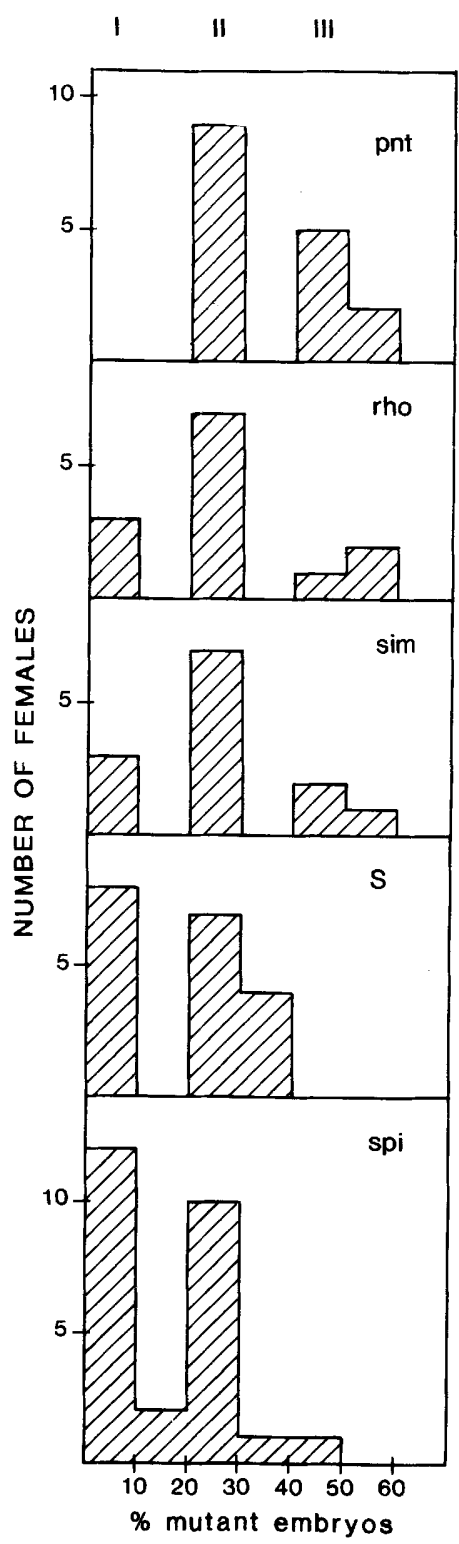

and sim. For these three genes, chromosomal deficiencies are available, allowing the determination of the lack of function condition. However, homozygous mutant embryos are obtained normally from heterozygous parents. If the genés were transcribed during oogenesis, the gene product would be already present in the egg and thus possibly weaken the amorphic zygotic phenotype. It is also possible that the genes, despite their seemingly region-specific requirement, have more general functions at other times in development or in other cell types. To test these possibilities, we constructed females with germ lines that were homozygous mutant and compared their progeny with those from heterozygous females.

To obtain germ line soma chimeras of the spitz-group mutants, we transplanted pole cells from mutant donor embryos into recipient embryos carrying the dominant female-sterile mutation ${ }{ }^{D} O^{D}$ (see Materials and methods; Busson et al. 1983|. ovo $/+$ females do not lay eggs due to a cell-autonomous defect of the germ line (Perrimon 1984). Thus, any progeny produced by these females after pole cell transplantation must derive from the donor germ cells. The genotype of the germ line in chimeric females was determined by the frequency of mutant embryos in crosses with heterozygous mutant males.

Fertile host females produced either no mutant embryos (class I), or about $25 \%$ (class II) or roughly $50 \%$ (class III) mutant embryos (Fig. 9). Class III females were presumed to carry homozygous mutant germ cells. Such females were found for pnt, rho, and sim and they produced homozygous mutant embryos that did not differ phenotypically from those produced by regular crosses. Thus, these three genes are apparently not required for

Figure 9. Assay for maternal effect of zygotic spitz-group mutants by pole cell transplantation into agametic recipients. Proportion of mutant embryos laid by individual host females. Genotypes of donor embryos: class I, balancers (CyO/CyO, TM3/MRS, TM3/TM6); class II, heterozygotes; and class III, homozygotes (see text). 
normal development of the germ line, nor do they show any maternal influence on embryonic development. By contrast, no host females of class III were identified in the case of $S$ or spi donor crosses with the exception of a single case. The exceptional spi chimeric female produced very few eggs, which were smaller than normal and also poorly differentiated. The classification of spi females as class I or II was confirmed by scoring the phenotype of their adult progeny (see Materials and methods). Thus the lack of class III females implies that the $S$ and spi genes are required for normal development of the female germ line, suggesting that these two genes may be involved in more general cell functions.

\section{The maternal gene sichel, a member of the spitz group}

In a screen for maternal mutants on the third chromosome, four mutations were identified which resulted in a phenotype similar to those of the zygotic spitz group (C. Nüsslein-Volhard et al., unpubl.). These mutants are all alleles of a single gene sichel (sic), which maps by meiotic recombination between pink and curled at 48.8 and cytologically to 85D7-12 (Mayer 1986).

All four sic alleles produce, in addition to embryos with the spitz phenotype, normal-looking embryos that hatch and others that die before blastoderm formation. To test whether this variability in phenotype was dependent on the paternal genotype, we compared the phenotypes of embryos obtained from crosses of mutant females with mutant versus wild-type males. No differences were observed, indicating that all the phenotypic traits including their variability, are exclusively dependent on the genotype of the mother. We also tested whether the sic phenotype varies with temperature. Although the proportions of the different phenotypes varied with temperature $\left(18,25\right.$, and $\left.29^{\circ} \mathrm{C}\right)$ and from one experiment to another they did not show any specific temperature dependence. Of the four alleles $s^{2} c^{215}$ consistently produces fewer spitz and more normal-looking embryos and may therefore be regarded as the weakest allele. However, $s i c^{215}$ produces about the same proportion of early dying embryos as the other three alleles.

All four sic alleles were ethylmethane sulfonate (EMS)-induced mutations, raising the possibility that they may not be null mutations. We therefore compared the phenotypic effects of homozygous sic females to those hemizygous females such as sic/Df(3R) $\beta_{2} \mathrm{t}$ or sic/ $\mathrm{Df}\left(3 \mathrm{R} / \mathrm{by}^{10}\right.$. The mutant phenotype including its high variability is not significantly different in hemizygous females suggesting that the mutant sic alleles correspond to the lack of gene function.

\section{Early development of sic embryos}

Maternal mutants often show morphologically visible deviations from normal development in early embryogenesis. In sic embryos, we observed only slight deviations, such as a shallow head fold, a small anlage of the anterior midgut, and slow gastrulation movements. However, these abnormalities could not be correlated with the differentiated phenotype, as both normally and abnormally gastrulating embryos produced normal larvae as well as those displaying the spitz phenotype.

To determine whether specific defects could be detected in the embryos that die early in development, 0 to 2-hr-old embryos were stained with DAPI, which allows visualization of the nuclei (Russell et al. 1975). Figure 10A shows a sic embryo at the syncytial blastoderm stage, in which the nuclei are regularly dispersed and not distinguishable from a wild-type embryo of the same age. In contrast, the embryo in Figure 10B shows an irregular distribution of the nuclei, and we believe that this embryo corresponds to one which would later fail to differentiate cuticle. Thus, early development can become abnormal in the absence of the sic gene function. However, not all mutant embryos develop abnormally suggesting that there is no absolute requirement for the sic gene function for normal development.

\section{Germ line autonomy of the sic gene}

The different phenotypic classes produced by sic females raised the possibility that the genotype of both the germ line cells and the somatic cells of the follicle contributed to the mutant embryonic phenotypes. For example, only one of the mutant phenotypes might be produced if mutant sic germ line cells developed in a normal somatic environment. Alternatively, only one or the other component of the follicle might be responsible for the heterogeneity of sic embryonic phenotypes. To test these possibilities, we transplanted sic pole cells into $\mathrm{ovO}^{\mathrm{D} /+}$ hosts as described above for the other mutants. With maternal-effect mutants it is in principle possible to transplant mutant pole cells only. However, sic females
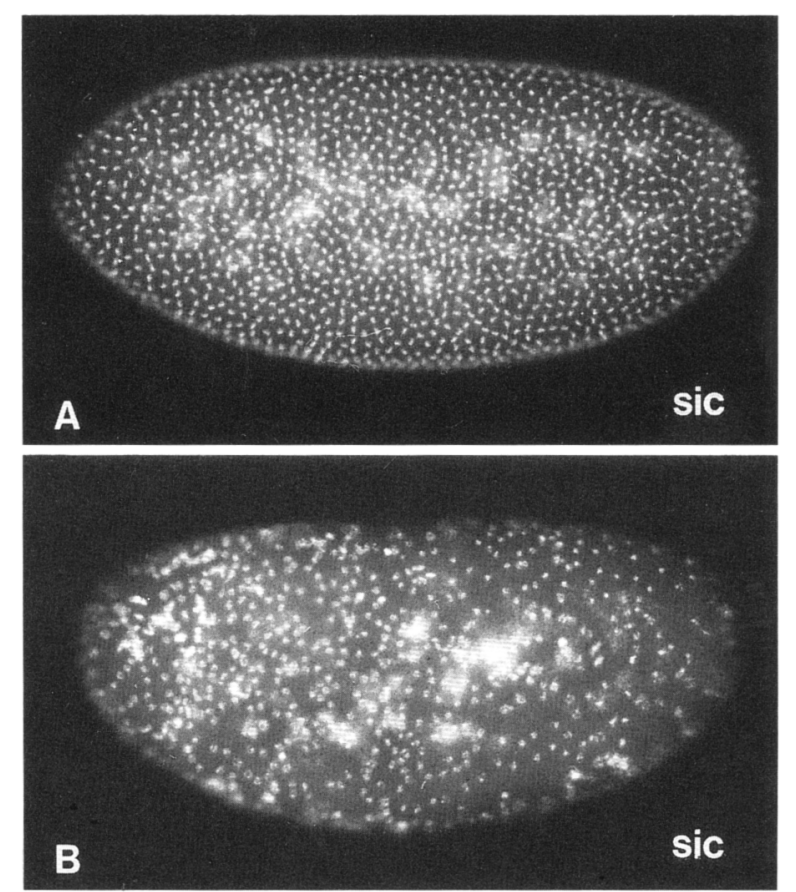

Figure 10. Different classes of embryos from sichel homozygous females as revealed by DAPI staining at the syncytial blastoderm stage. (A) Regular distribution of nuclei; $(B)$ abnormal spacing of nuclei. 
produce embryos that appear to have fewer pole cells than wild-type embryos, therefore we used heterozygous females, mated to homozygous males as parents of the donors. After transplantation, 11 fertile females were recovered, two of which produced at least some progeny with the spitz phenotype. Again there was the same phenotypic variability including hatching larvae and undifferentiated embryos, although the mutant germ cells developed surrounded by wild-type follicle cells. We conclude from this result that the mutation sic is germ-line dependent.

\section{Discussion}

\section{Region-specific requirements of spitz-group genes}

Unlike the anterior-posterior pattern, the dorsal-ventral axis of the embryo is not subdivided into segments. Furthermore, there is a scarcity of cuticular structures with well-defined, dorso-ventral positions that would allow one to localize mutant defects to a particular level along this axis. Despite these difficulties the phenotypes produced by the class of genes analyzed in this paper can best be described as affecting ventro-lateral pattern elements that develop from a longitudinal stripe along the entire anterior-posterior length of the embryo. Certain mutant phenotypes do display some more dorsal defects particularly in the head and tail. These can be explained as the secondary consequences of the effects of the ventro-lateral disruptions caused by these mutations on the cell movements of gastrulation and head involution. The spitz-group genes can be subdivided into different classes according to the exact ventro-lateral positions of the cuticular or PNS structures affected by mutations in these loci. At least two patterns can be distinguished by projecting the defects observed in differentiated embryos onto the blastoderm fate map (Fig. 11B,C). Mutations in the sim gene affect structures originating from a strip of blastodermal cells bordering the ventral midline and the anlagen of certain sense organs (Ant, $\mathrm{Mx}, \mathrm{Li}$, and $\mathrm{KO}$ ), while the other zygotic members of the spitz group delete or alter the organization of structures derived from more lateral positions (including the sense organs that define the lateral extent of sim). Thus, sim mutations affect a more ventral strip of epidermal cells relative to mutations in the other genes.

In addition to the cuticular phenotypes, mutations in all six of these genes also affect the CNS. As it is not known from which precursors the different elements of the CNS originate, it is not possible to assign the CNS defects to particular dorso-ventral positions. However, sim mutations are the only ones that eliminate the commissures connecting the left and right halves of the segmental ganglia, while mutations in the other zygotic genes merely change the length of the commissures. This suggests that as in the epidermis sim mutations affect more ventral structures than do mutations in the other genes. A similar correlation between epidermal and CNS defects is observed in pnt mutations, in that they cause the elements of certain (Ant, $\mathrm{Mx}, \mathrm{Li}$, and $\mathrm{KO}$ ) sense organs to stand further apart from one another and also widen the space between the left and right halves of segmental ganglia. Thus, the effects of the spitz-group mutations on the epidermis and the nervous system, including the PNS and the CNS, are essentially similar, indicating that these genes perform a region-specific rather than an organ-specific role in development. The correlation between the epidermal and CNS phenotypes also suggests that these genes act early in development before the ventral neuroblasts segregate from the ventral ectoderm.

This conclusion has been confirmed for sim, which a recent molecular analysis has shown to be expressed, before the neuroblasts segregate from the remaining ventral ectoderm (Crews et al. 1988; Thomas et al. 1988). The sim gene is first transcribed at cellular blastoderm in two rows of $1-2$ cells that come to lie immediately adjacent to the invaginating mesoderm and subsequently give rise to midline neuroblasts (and some cells of the foregut). Loss of the cells that express $\operatorname{sim}$ would explain the fusion of the left and right halves of the ganglia in sim mutant embryos, but would not account for the epidermal phenotype we observe. The epidermal phenotype can be explained readily, however, if one assumes that the midline cells expressing the sim product also give rise to epidermal cells, as well as neuroblasts. This notion is supported by observations of $\mathrm{V}$. Hartenstein (pers. comm.).

It has been shown previously that many zygotically lethal mutations are also lethal in the female germ line, whereas most of the genes involved specifically in embryonic pattern formation are not (Perrimon et al. 1984; Wieschaus and Noell 1986). Thus, germ line lethality is an excellent criterion by which genes coding for more general functions can be recognized. In addition, it is known that genes involved in the development of only part of the embryo, such as segmentation or homeotic selector genes, generally are exclusively zygotically ex-

Figure 11. (See p. 1508.) Projection of pattern defects observed in the cuticle of spitz-group mutants onto the blastoderm fate map. (A) Composite fate map based on data of Lohs-Schardin et al. (1979), Campos-Ortega and Hartenstein (1985), Jürgens et al. (1986), and Jürgens (1987). The region marked by vertical lines and bounded by the dotted line gives rise to the ventral denticle bands and ventral naked cuticle. The ventral neurogenic region of the thorax and abdomen is represented by horizontal lines. The dorsal and posterior limits are shown by dashed lines. The anlagen of endodermal (AMG, PMG) and mesodermal (Ms) structures are marked off against the ectoderm according to Hartenstein et al. (1985). (B) Defect zone of single-minded embryos. (C) Defect zone of Star, spitz, rhomboid, and pointed embryos (for details, see text). (AMG) Anterior midgut; (Ant) antennal sense organ; (ap) anal pads; (Ci) cirri; (DA) dorsal arm; (dbd) dorsal black dot; (DBr) dorsal bridge; (H) H-bridge; (HO) hypopharyngeal organ; (KO) Keilin's organ; (LG) Lateralgräte; (lH) lateral sensory hair; (Li) labial sense organ; (lr) labral sense organ; $(\mathrm{MH})$ mouth hooks; (Ms) mesoderm; (Mx) maxillary sense organ; $(\mathrm{ppw})$ posterior wall of pharynx; $(\mathrm{t})$ tuft $_{i}(\mathrm{~T}) \mathrm{T}$-ribs (floor of pharynx); (VA) ventral arm; (vbd) ventral black dot; (VP) vertical plate. Symbols: $(\bullet)$ thoracic black dots and $\mathrm{HO}$; $(0)$ sense organs of the head; $(\triangle)$ other cuticle structures of the head; $(\lambda)$ trihairs, $\mathrm{KO} ;\left({ }^{*}\right)$ tuft. 
pressed (Frohnhöfer 1982; Lawrence et al. 1983; Nüsslein-Volhard et al. 1985) and mutant embryos exhibit the same phenotype, regardless of the presence or absence of the gene function in the female germ line. When applied to the results of our pole cell transplanta- tion experiments, the two criteria described above suggest that sim, rho, and pnt are expressed specifically in the embryo, as mutant female germ cells develop normally and mutant oocytes do not alter the phenotype of mutant embryos. By contrast, $S$ and spi, which are re-
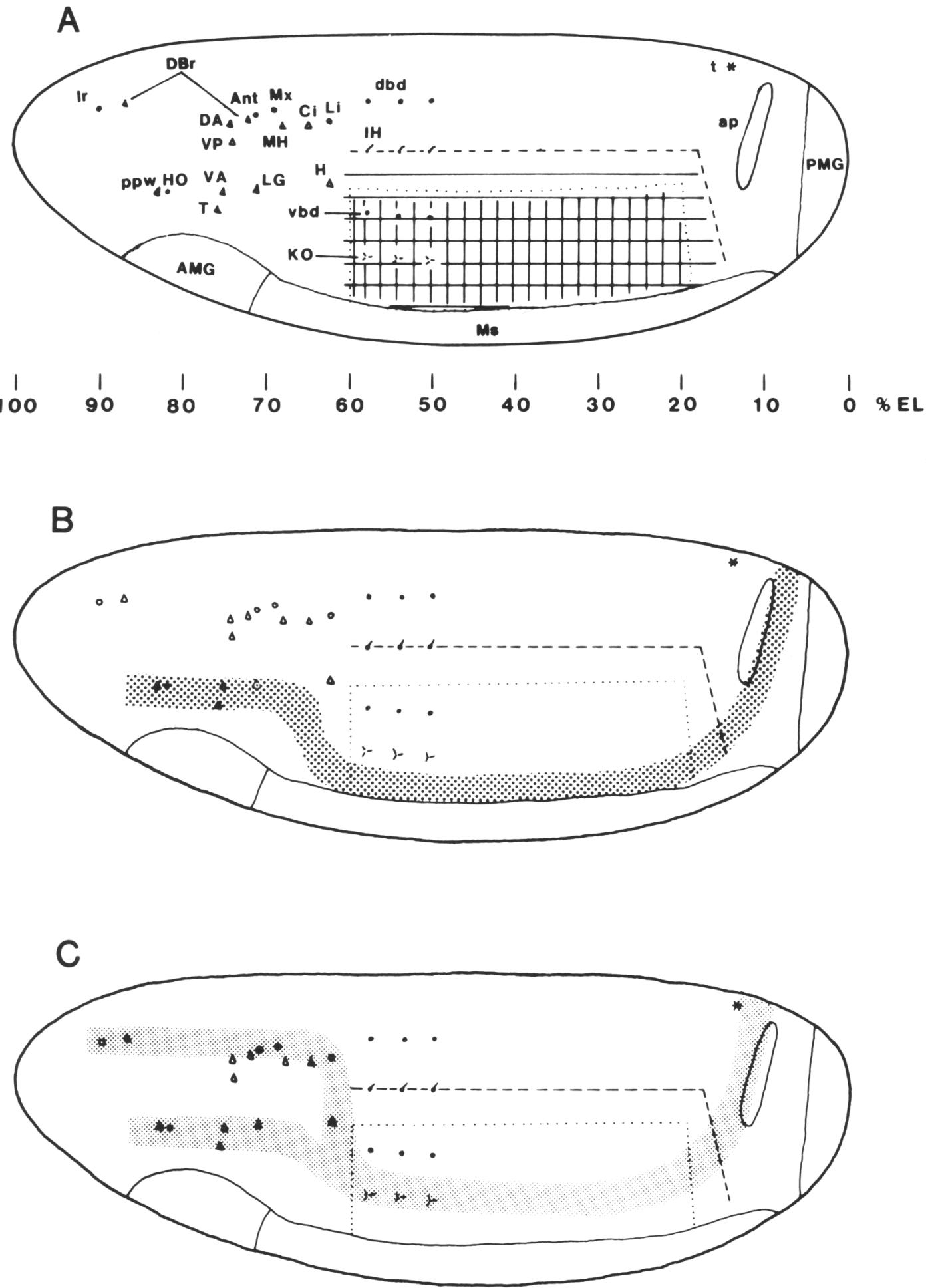

Figure 11. (See previous page for legend.) 
quired in both the embryo and the female germ line, may code for more general cell functions. This leads to the prediction that of the zygotic genes in the class whose embryonic expression patterns have not been described yet, rho and pnt are most likely to be expressed in longitudinal stripes like sim. If rho and pnt are required in a specific longitudinal strip of cells, the functions of these genes within these cells are likely to be different. While rho deletes structures that develop from a particular ventro-lateral position, in pnt mutant embryos these structures are still present but disorganized.

The maternal gene sic may be included in the same category as $S$ and $s p i$, as this gene does not appear to be absolutely required for normal development. Furthermore, the spitz phenotype occurs only in some of those embryos that have passed an early critical step in embryogenesis when cleavage nuclei arrive at the peripheral cortex layer.

\section{What is the significance of the spitz phenotype for dorso-ventral patterning?}

That maternally provided information for dorso-ventral patterning is translated into region-specific zygotic gene activity is well documented for zen and twi. zen is expressed in the dorsally located presumptive amnioserosa and $t w i$ in the ventral furrow which gives rise to the mesoderm (Rushlow et al. 1987; Thisse et al. 1987). The intervening embryonic ectoderm was thought to be subdivided coarsely into a dorsal and a ventral region on the basis of the phenotypes and expression pattern of neurogenic genes (Lehmann et al. 1983; Vässin et al. 1987). However, the pattern of $d p p$ expression (St. Johnston and Gelbart 1987) raised the possibility that the ectoderm might be subdivided into a series of longitudinal stripes, even though the epidermis of the mature embryo forms an integrated dorso-ventral pattern. The mutant phenotypes of the spitz-group genes provide further evidence for additional subdivisions of the ventral ectoderm. The sim gene is required and expressed in a narrow ventral strip adjacent to the mesoderm (Crews et al. 1988; Thomas et al. 1988). The other zygotic spitzgroup genes are required in a more ventro-lateral region, although only two of them, rho and pnt, might be involved specifically in its development. It remains to be seen whether our inferences about the other spitz-group genes will also be confirmed at the molecular level when cloned probes for in situ hybridization studies become available.

\section{Materials and methods}

All marker mutants and balancers used in this study are described in Lindsley and Grell (1968). The wild-type stock was Oregon R. Stocks were maintained on standard Drosophila food, and embryos were collected according to Nüsslein-Volhard et al. (1984). All mutant chromosomes carried suitable marker mutations.

\section{Strains}

All spitz-group mutations were recovered in systematic largescale screens of the second and third chromosome (Jürgens et al. 1984; Nüsslein-Volhard et al. 1984; C. Nüsslein-Volhard et al., unpubl.). The mutant alleles used in this paper are listed in Table 1 . The deficiencies $\mathrm{Df}(3 \mathrm{R})$ by ${ }^{10}$ and $\mathrm{Df}(3 \mathrm{R}) \mathrm{\beta}_{2} \mathrm{t}$ were kindly provided by T. Kaufman (Kemphues et al. 1983).

\section{Analysis of embryonic phenotypes}

For cuticle preparations, differentiated embryos were dechorionated, freed from the vitelline membrane with a fine needle, fixed in $1: 4$ mixture of glycerol and acetic acid, and embedded in a $1: 1$ mixture of Hoyer's medium and lactic acid (van der Meer 1977; Wieschaus and Nüsslein-Volhard 1986).

\section{Antibody staining}

The monoclonal antibody $22 \mathrm{C} 10$, a gift from A. Ferrus, was used to analyze the mutant embryonic peripheral nervous system at about stage 14 .

To visualize the CNS, embryos were stained with the antibody against horseradish peroxidase (anti-HRP), which exhibits a conspicuous affinity for the membranes of both mature and immature neural cells (Jan and Jan 1982). The method has been described previously by V. Hartenstein (1987).

The polyclonal even-skipped antibody was kindly provided by $M$. Frasch. Staining procedure of whole-mount embryos with biotinylated horseradish peroxidase avidin complexes bound to biotinylated second antibody /Vector Laboratories, Avidin Biotin $\mathrm{ABC}$ system) was carried out as described by Macdonald and Struhl (1986).

Transplantation of pole cells from spitz-group mutant embryos and progeny testing of host females

The protocol for the transplantation of pole cells has been described (Nüsslein-Volhard et al. 1985). Hatch rates and frequency of mutant embryos were determined as described by Nüsslein-Volhard (1977). Recipient embryos were produced by Oregon R females crossed with ovo ${ }^{D}$ males (Busson et al. 1983). Donor embryos were obtained from the following crosses: (1)

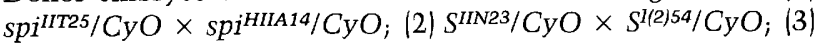
$\operatorname{sim}^{E 320-5 / T M 3}, \quad S b \times \operatorname{sim}^{1(3) / S 8} / M K R S, \quad S b ; \quad(4) \quad r h o^{7 M 43} / T M 3$, $S b \times r h o^{7 M 43}, \operatorname{sim}^{\text {E320-5/TM6; (5) }}$ pnt $^{8874 / T M 3}, \quad S b \times$ pnt $^{\text {9131/ }}$ $T M 3, S b$. For $s p i$, the genotypes of donor pole cells were confirmed by scoring the phenotypes of adult progeny produced by the host females mated to $D f(2 L) E 55$, spi-pr/CyO males.

\section{Acknowledgments}

We thank G. Jürgens and our colleagues in the laboratory for stimulating and critical discussion, and Leslie Stevens for valuable comments on the manuscript. The help of R. Grömke-Lutz and D. Eder in producing the figures and V. Koch in typing the manuscript is gratefully acknowledged.

\section{References}

Anderson, K.V. 1987. Dorsal-ventral embryonic pattern genes in Drosophila. Trends Genet. 3: 91-97.

Anderson, K.V., L. Bokla, and C. Nüsslein-Volhard. 1985a. Establishment of dorsal-ventral polarity in the Drosophila embryo: The induction of polarity by the Toll gene product. Cell 42: 791-798.

Anderson, K.V., G. Jürgens, and C. Nüsslein-Volhard. 1985b. Establishment of dorsal-ventral polarity in the Drosophila embryo: Genetic studies on the role of the Toll gene product. Cell 42: 779-789.

Busson, D., M. Gans, K. Komitopoulou, and M. Mason. 1983. Genetic analysis of three dominant female-sterile mutations located on the X-chromosome of Drosophila melanogaster. 
Genetics 105: 309-325.

Campos-Ortega, J.A. and V. Hartenstein. 1985. The embryonic development of Drosophila melanogaster. Springer Verlag, Berlin.

- 1985. 2: Development of the nervous system. In Comprehensive insect physiology biochemistry and pharmacology: Vol. 5: Nervous sytem: Structure and motor function (ed. G.A. Kerkut and L.I. Gilbert), pp. 49-83. Pergamon Press, New York.

Crews, S.T., J.B. Thomas, and C.S. Goodman. 1988. The Drosophila single-minded gene encodes a nuclear protein with sequence similarity to the per gene product. Cell 52: 143-151.

Doyle, H.J., K. Harding, T. Hoey, and M. Levine. 1986. Transcripts encoded by a homeo box gene are restricted to dorsal tissues of Drosophila embryos. Nature 323: 76-79.

Frasch, M., T. Hoey, C. Rushlow, H. Doyle, and M. Levine. 1987. Characterization and localization of the even-skipped protein of Drosophila. EMBO J. 6: 749-759.

Frohnhöfer, H.G. 1982. Ph.D. thesis. Abgrenzung maternaler und zygotischer Anteile bei der genetischen Kontrolle der Musterbildung in Drosophila melanogaster. Tübingen, FRG.

Hartenstein, V. 1987. The influence of segmental compartmentalisation on the development of the larval peripheral nervous system in Drosophila melanogaster. Wilhelm Roux's Arch. Dev. Biol. 196: 101-112.

Hartenstein, V., G.M. Technau, and J.A. Campos-Ortega. 1985. Fate mapping in wild-type Drosophila melanogaster. III. A fate map of the blastoderm. Wilhelm Roux's Arch. Dev. Biol. 194: 213-216.

Hartenstein, V. and J.A. Campos-Ortega. 1986. The peripheral nervous sytem of mutants of early neurogenesis in Drosophila melanogaster. Wilhelm Roux's Arch. Dev. Biol. 195: 210-221.

Hilliker, A.J., S.H. Clark, W.M. Gelbart, and A. Chovnick. 1981. Cytogenetic analysis of the rosy micro-region, polytene chromosome interval 87D2-4; E12-F1, of Drosophila melanogaster. Dros. Info. Service 56: 65.

Jan, L.Y. and Y.N. Jan. 1982. Antibodies to horseradish peroxidase as specific neuronal markers in Drosophila and grasshopper embryos. Proc. Natl. Acad. Sci. 72: 2700-2704.

Jürgens, G. 1987. Segmental organisation of the tail region in the embryo of Drosophila melanogaster. A blastoderm fate map of the cuticle structures of the larval tail region. Wilhelm Roux's Arch. Dev. Biol. 196: 141-157.

Jürgens, G., E. Wieschaus, C. Nüsslein-Volhard, and H. Kluding. 1984. Mutations affecting the pattern of the larval cuticle in Drosophila melanogaster. II. Zygotic loci on the third chromosome. Wilhelm Roux's Arch. Dev. Biol. 193: $283-295$.

Jürgens, G., R. Lehmann, M. Schardin, and C. Nüsslein-Volhard. 1986. Segmental organisation of the head in the embryo of Drosophila melanogaster. A blastoderm fate map of the cuticle structures of the larval head. Wilhelm Roux's Arch. Dev. Biol. 195: 359-377.

Kemphues, K.J., E.C. Raff, and T.C. Kaufman. 1983. Genetic analysis of $\mathrm{B} 2 \mathrm{t}$, the structural gene for a testis-specific betatubulin subunit in Drosophila melanogaster. Genetics 105: 345-356.

Lawrence, P.A., P. Johnston, and G. Struhl. 1983. Different requirements for homeotic genes in the soma and germ line of Drosophila. Cell 35: 27-34.

Lehmann, R., F. Jimenez, U. Dietrich, and J.A. Campos-Ortega. 1983. On the phenotype and development of mutants of early neurogenesis in Drosophila melanogaster. Wilhelm Roux's Arch. Dev. Biol. 192: 62-74.
Lindlsey, D.L. and E.H. Grell. 1968. Genetic variations of Drosophila melanogaster. Carnegie Inst. Wash. Publ. 627.

Lohs-Schardin, M., C. Cremer, and C. Nüsslein-Volhard. 1979. A fate map for the larval epidermis of Drosophila melanogaster: Localized cuticle defects following irradiation of the blastoderm with an ultraviolet laser microbeam. Dev. Biol. 73: 239-255.

Macdonald, P.M. and G. Struhl. 1986. A molecular gradient in early Drosophila embryos and its role in specifying the body pattern. Nature 324: 537-545.

Mayer, U. 1986. Ph.D. thesis. Phänotypische und genetische Untersuchungen an Genen der spitz-Gruppe von Drosophila melanogaster. Tübingen, FRG.

Nüsslein-Volhard, C. 1977. A rapid method for screening eggs from single Drosophila females. Dros. Info. Service 52: 166.

Nüsslein-Volhard, C., E. Wieschaus, and H. Kluding. 1984. Mutations affecting the pattern of the larval cuticle in Drosophila melanogaster. I. Zygotic loci on the second chromosome. Wilhelm Roux's Arch. Dev. Biol. 183: 267-282.

Nüsslein-Volhard, C., H. Kluding, and G. Jürgens. 1985. Genes affecting the segmental subdivision of the Drosophila embryo. Cold Spring Harbor Symp. Quant. Biol. 50: 145-154.

Perrimon, N. 1984. Clonal analysis of dominant female-sterile germline-dependent mutations in Drosophila melanogaster. Genetics 108: 927-939.

Perrimon, N., L. Engstrom, and A.P. Mahowald. 1984. The effects of zygotic lethal mutations on female germ-line functions in Drosophila. Dev. Biol. 105: 404-414.

Rushlow, C., M. Frasch, H. Doyle, and M. Levine. 1987. Maternal regulation of zerknüllt: A homeobox gene controlling differentiation of dorsal tissues in Drosophila. Nature 330: $583-586$.

Russell, W.C., C. Newman, and D.H. Williamson. 1975. A simple cytochemical technique for demonstration of DNA in cells infected with mycoplasmas and viruses. Nature 253: $461-462$.

St. Johnston, D.R. and W. Gelbart. 1987. Decapentaplegic transcripts are localized along the dorsal-ventral axis of the Drosophila embryo. EMBO I. 6: 2785-2791.

Szabad, I., T. Schüpbach, and E. Wieschaus. 1979. Cell lineage and development in the larval epidermis of Drosophila melanogaster. Dev. Biol. 73: 256-271.

Thisse, B., C. Stoetzel, M. El Messal, and F. Perrin-Schmidt. 1987. Genes of the Drosophila maternal dorsal group control the specific expression of the zygotic gene twist in presumptive mesodermal cells. Genes Dev. 1: 709-715.

Thomas, J.B., S.T. Crews, and C.S. Goodman. 1988. Molecular genetics of the single-minded locus: A gene involved in the development of the Drosophila nervous system. Cell 52: 133-141.

Vässin, H., K.A. Bremer, E. Knust, and J.A. Campos-Ortega. 1987. The neurogenic gene Delta of Drosophila melanogaster is expressed in neurogenic territories and encodes a putative transmembrane protein with EGF-like repeats. EMBO I. 6: 3431-3440.

van der Meer, J.M. 1977. Technical notes: Optical clean and permanent whole mount preparation for phase-contrast microscopy of cuticular structures of insect larvae. Dros. Info. Service 52: 160.

Wakimoto, B.T., F.R. Turner, and T.C. Kaufman. 1984. Effects in embryogenesis in mutants associated with the antennapedia gene complex of Drosophila melanogaster. Dev. Biol. 102: $147-172$.

Wieschaus, E. and E. Noell. 1986. Specificity of embryonic lethal mutations in Drosophila analyzed in germ line clones. Wilhelm Roux's Arch. Dev. Biol. 195: 63-75. 
Wieschaus, E. and C. Nüsslein-Volhard. 1986, Looking at embryos. In Drosophila: A practical approach (ed. D.B. Roberts), pp. 199-227. IRL Press, Oxford, Washington, D.C.

Zipursky, S.L., T.R. Venkatesh, and S. Benzer. 1985. From monoclonal antibody to gene for a neuron-specific glycoprotein in Drosophila. Proc. Natl. Acad. Sci. 82: 1855-1859. 


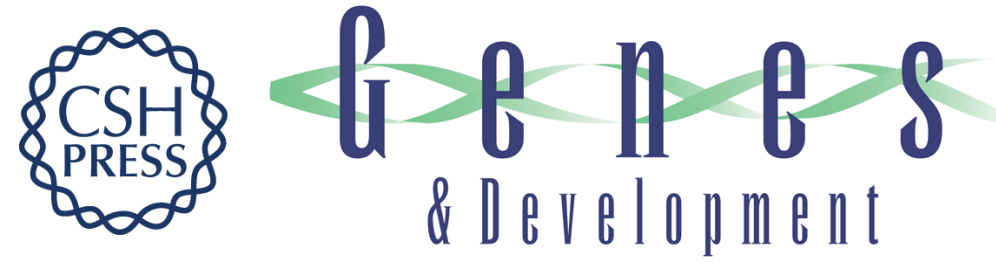

\section{A group of genes required for pattern formation in the ventral ectoderm of the Drosophila embryo.}

U Mayer and C Nüsslein-Volhard

Genes Dev. 1988, 2:

Access the most recent version at doi:10.1101/gad.2.11.1496

References This article cites 36 articles, 5 of which can be accessed free at:

http://genesdev.cshlp.org/content/2/11/1496.full.html\#ref-list-1

License

Email Alerting

Service

Receive free email alerts when new articles cite this article - sign up in the box at the top right corner of the article or click here.

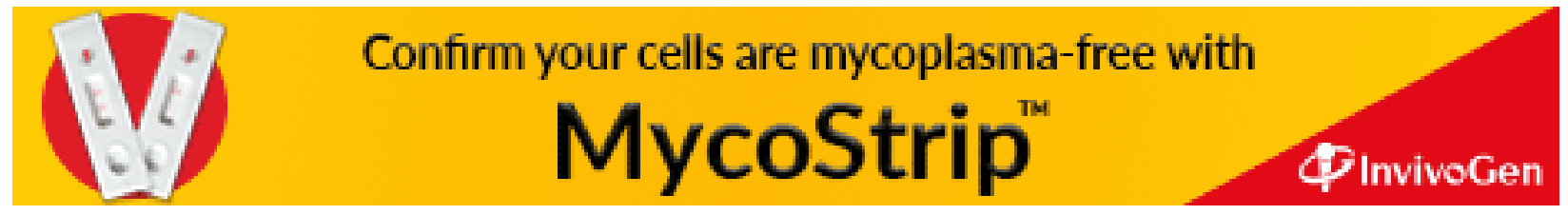

